tradition are members of other institutions, are selected by the Sloan-Kettering Division of Cornell University Medical College, the executive faculty of the Memorial Center.

\section{Gulmarg Research Observatory, Kashmir}

THE Universities of Aligarh and of Jammu and Kashmir have jointly established a high-altitude research station at Gulmarg in Kashmir, to be known as the Gulmarg Research Observatory, and the Observatory was officially declared open on April 4 by Prof. A. H. Compton, chancellor of Washington University. The Observatory, which is under the direction of Prof. P. S. Gill, head of the Department of Physics, Aligarh, is at a height of $9,000 \mathrm{ft}$., which, as Prof. Compton pointed out, compares favourably with other high-altitude laboratories such as Mexico City $(7,500 \mathrm{ft}$. and about the same magnetic latitude), Huancayo, Peru (10,500 ft.), Echo Lake, Colorado $(10,000 \mathrm{ft}$.$) and Jungfraujoch, Switzerland (11,300$ ft.). Work at higher altitudes is also possible at Khillan Marg (11,000 ft.), which is one hour distant, and at Apharvat (14,000 ft.), which is three hours distant. Prof. Compton, who was the first to initiate cosmic-ray studies in India when he carried out cosmic-ray measurements at Tosh Maidan, Kashmir, in 1926, continued: "The latitude and longitude are of special significance in cosmic-ray measurements, in comparing results with those obtained elsewhere. The latitude is that at which most rapid cosmic-ray changes occur with changing latitude. The longitude is close to that where maximum effects of the earth's magnetic field are felt. Comparison of results found here with those from other stations are thus of special significance with regard to the effects of the earth's magnetic field on the primary cosmic rays, a subject of major theoretical interest".

\section{Suffolk Naturalists' Society: Schools Supplement to Transactions}

THE encouragement of younger people in field natural history and practical biology should not be left entirely to the schools, especially since most observational work and recording has to be done at nearly all times of the year and out of school hours. Apart from this, there are certain institutions, especially local natural history societies, which can obviously offer keen enthusiasts special local information and other facilities which are not to be found elsewhere. Some natural history societies do much to encourage young people by inviting them to meetings and organizing excursions. The Suffolk Naturalists' Society has already done much in this connexion by establishing contact with the local schools and making them members; and now it has taken an even more effective step by publishing for the first time a Schools Supplement to its own Transactions $(8$, Part $3 ;$ 1953). The Supplement is intended to be a Schools' Natural History Societies' Journal, in which can be published observations and notes received from member schools-together with suggestions of simple work which schools or young naturalists may undertake. In this first issue is a very practical article on "Field Work on Hedges", giving an easily read account of the plant and animal ecology of hedges. This is followed by an article on "Mice and Voles", which not only informs but is also calculated to inspire and stimulate interest. 'Two shorter articles follow, on "Moles on Flooded Land" and "The Geology of Suffolk" (Part 2). Practical instructions are then given on how to use a micro- scope for explaining everyday experiences (in this case, why a nettle-leaf stings). Birds naturally loom large in the field naturalists' interest, so a short article on "Bird Identification in the Field" will prove very useful. There are two reports of biological work by young people: (1) "Investigations into Pellets of the Short-eared Owl" by John Petford; (2) "A Weed Study" carried out by Form II $B$ of Halesworth Area School.

This is an excellent journal from all points of view and will undoubtedly do much to encourage the development of interest in natural history in Suffolk and, it is hoped, well beyond the borders of the county. It is to be published twice a year. Further information concerning the objectives of the Suffolk Naturalists' Society and the Schools' Supplement to its Transactions can be obtained from the Earl of Cranbrook, Great Glenham House, Saxmund. ham, Suffolk.

\section{"Standardized Plant Names" in Australia}

THE booklet bearing this title is the revised version of a list, originally published in 1942, of standard common names for the more important Australian grasses, other pasture plants and weeds (Bull. No. 272, Commonwealth Scientific and Industrial Research Organization, Melbourne, Australia, 1953 ; n.p.). This new index, which runs to some 132 pages, is a thorough revision of the earlier work, the information having been drawn from all the many reliable sources available. The approved botanical name, its synonyms and the standard common names for each species are given in two lists which permit of simple cross-reference.

\section{Veterinaria Italiana}

THE first number of Veterinaria Italiana, a review of animal hygiene, prophylaxis and therapy, edited by the General Directorate of Italian Veterinary Services with Prof. Giuseppe Caporale as responsible editor, is an attractively produced journal, issued from the Experimental Zooprophylastic Institute, Teramo (No. 1, January 1954; obtainable from the Institute at c.c. postale N. $20 / 988$; no price). It is a monthly journal containing scientific and practical articles, together with news of veterinary medicine in Italy and the rest of the world. It is intended that the original articles shall have summaries in English, French and German; but in the first issue some articles are in Italian only. This first number is divided into a scientific and a practical part. In the scientific part Dr. L. Badiali writes on the use of isonicotinic acid hydrazide for the prophylaxis of bovine tuberculosis; Dr. A. Mantovini on the culture of canine disternper virus on the chorio-allantoic membranes of eggs ; Prof. V. Cilli on animal diseases transmissible to man; and Dr. G. Guarini on the complement deviation reaction for the diagnosis of infective anæmia of the horse. The practical part of the journal contains notes on the therapy of a number of diseases, and the number is completed by reviews of books, abstracts of current veterinary literature and veterinary news. Veterinarians and others interested in the remarkable recent advances in veterinary science will watch the progress of this new journal with interest.

\section{Geographical Studies}

WITH the geographical staffs in United Kingdom universities now almost double their pre-war numbers, 